\title{
MENINGITE TUBERCULOSA TRATADA COM ESTREPTOMICINA
}

\author{
MARIO MURSA * \\ JOAO BAPTISTA DOS REIS** \\ J. RENATO WOISKI ***
}

Depois do aparecimento das sulfas, a terapêutica deu mais um agigantado passo com o advento dos antibióticos. Em seguid $a$ aos sucessos da Penicilina, começam a ser divulgados, agora, os êxitos da Estreptomicina que, sob certos aspectos, parece ser superior à primeira. A atividade dos pesquisadores tem sido intens $\mathrm{a}_{\mathrm{a}}$ e a eficácia dêste medicamento no tratamento da tuberculose, especialmente na meningite tuberculosa, tem sido verificada com esperanças bem fundadas de sucesso. Em recente visita de estudos à América do Norte, dois de nós havíamos observado no Serviço do Prof. S. Lavine, no New York Hospital, um caso desta moléstia tratado com o novo antibiótico e que, depois de prolongada observação, não apresentava recidivas. Há cêrca de 4 meses, tivemos oportunidade de observar e tratar um caso semelhante. Como ainda é dificil obter êsse medicamento em doses suficientes e como os casos publicados no estrangeiro são muito escassos, julgamos que a presente observação possa despertar certo interêsse por ser, talvez, a primeira publicada na literatura nacional. Antigamente sabia-se como a moléstia caminhava para seu desfêcho fatal. Hoje não conhecemos ainda muito bem como ela evolui para a cura, como se comportam os diferentes sintomas, como evolui a curva térmica, quais as modificações que sofrem os elementos do líqüido cefalorraquidiano, quais as sequelas e possibilidades de recidivas. Estas incógnitas tôdas embaraçaram nossa taref $_{a}$ e não foram poucos os problemas que tivemos de enfrentar. As dificuldades na manipulação do medicamento, as reações que provocou e o modo pelo qual se processou a cura, exigem que a observação, embora se torne fastidiosa, seja relatada com certa minúcia.

J. M. M., com 5 anos de idade, filho único de pais sadios, de constituição neuropática e com antecedentes mórbidos de pouca monta, exceto sarampo e va-

Trabalho apresentado à Seç̧ão de Pediatria (13-1-947) e à Seç̧ão de Neuropsiquiatria (5-2-947) da Associação Paulista de Medicina. Entregue para publicação em 6 fevereiro 1947.

* Diretor do Hospital de Crianças da Cruz Vermelha.

* Assistente Laboratorista do Serviço de Neurologia da Escola Paulista de Medicina (Prof. Paulino Longo).

*** Assistente e livre-docente de Pediatria da Escola Paulista de Medicina (Prof. Pedro le Alcantara). 
ricela sem complicações que o acometeram aos 4 anos de idade. Mês e meio antes do início da moléstia atual, descobriu-se que sua pagem era tuberculosa; ela teve uma hemoptise e, examinada, foi verificado que era portadora de cavernas antigas e recentes. Todos em casa foram examinados à radioscopia, inclusive o paciente, nada de positivo tendo sido encontrado. Uma semana depois dêstes fatos, fomos chamados para prestar-lhe assistência. J. M. estava febril. Tratava-se de afecção sem causa aparente e com bom estado geral. Suspeitou-se logo da tuberculose. A radiografia, embora não concludente, apresentava imagem suspeita na região hilar direita. O hemograma acusava leucocitose com mononucleose, tendência à neutropenia, acentuado desvio para a esquerda e presença ie numerosas formas atípicas de linfócitos e monócitos. Este quadro fazia pensar em mononucleose, mas a ausência de gânglios e outros sinais clínicos não justificaav êsse diagnóstico. Além disso, a reação à tuberculina resultara fortemente positiva, o que trouxe um elemento ponderável para a possibilidade de infecção específica. Dentro de 15 dias a febre cedeu gradativamente e tudo parecia voltar ao normal: o paciente recuperou pêso, alimentava-se bem e apresentava excelente estado geral. Mas essa normalidade foi apenas uma trégua. Duas semanas depois apresentou inapetência, cefaléia a princípio esporádica e tornando-se com o tempo mais intensa, vómitos ocasionais e leve hipertermia, enfim, o início silencioso da meningite tuberculosa. Em poucos dias êstes sintomas se acentuaram, acrescidos de pulso irregular e bradicárdico, raia maníngea, prisão de ventre e fases de excitação alternada com torpor. A punção suboccipital forneceu líquor hipertenso, levemente opalescente, formando-se delicado retículo fibrinoso; havia hipercitose de 186 células por mm." (98\% de linfócitos), 0,50 gr. de proteínas totais, $6.73 \mathrm{grs}$. de cloretos e $0,43 \mathrm{gr}$. de glicose por litro, respectivamente; reação de Takata-Ara positiva, de tipo vermelho; reação de Wassermann negativa; exame bacterioscópico direto negativo para bacilos álcool-ácido-resistentes. Estes elementos mostravam a grande probabilidade do diagnóstico de meningite tuberculosa. Em tais circunstâncias declaramos à família que exsitia a possibilidade de cura com a Estreptomicina e, tais foram os esforços para obtê-la que, 5 dias mais tarde, já a tínhamos em mãos. Enquanto aguardávamos a chegada do medicamento, diligenciamos em manter a alimentação por sonda duodenal e levantar as fôrças do doente com transfusões de sangue, mantendo também seu equilíbrio hídrico com plasma, aminoácidos e solução glicofisiológica por via intravenosa.

A primeira injeção de estreptomicina foi feita no $8 .^{\circ}$ dia da moléstia declarada ou, mais precisamente, no $15 .^{\circ}$ dia do aparecimento dos primeiros sinais $d^{\prime}$ infecção. Nesse dia a situação era a seguinte: torpor, vómitos, cefaléia, respiração de tipo Cheyne-Stokes, bradicardia de 50-80 pulsações por minuto, dermografismo, rigidez de nuca não muito acentuada, ptose da pálpebra direita, rigidez pupilar, leve estrabismo divergente esquerdo. O torpor era intercortado por fases de agitação e gritos. A temperatura se mantinha em tôrno de $38^{\circ} \mathrm{C}$. De acôrdo com as instruções fornecidas pela comissão americana para estudos sôbre a Estreptomicina, resolvemos iniciar o tratamento diàriamente com $150.000 \mathrm{U}$. por via intramuscular, de 3 em 3 horas, ou sejam $1.200 .000 \mathrm{U}$. cada 24 horas, e ao mesmo tempo, de 12 em 12 horas, uma injeção raqueana de 25.000 U.. Logo em seguida à primeira injeção intra-raqueana apareceu violenta cefaléia e a temperatura elevou-se consideràvelmente, atingindo $40,1^{\circ} \mathrm{C}$, persistindo durante parte da noite. Ao amanhecer, a situação persistia a mesma, mas no dia seguinte verificamos sinais de melhoras: desaparecimento do torpor e volta da consciência, pois o paciente respondia fàcilmente às perguntas, embora queixando-se de dor de cabeça; entretanto, a ptose palpebral se havia acentuado e o estrabismo não se modiifcara. Não havia mais respiração de Cheyne-Stokes. O pulso era cheio, rítmico e mais freqüente. As melhoras foram tão surpreendentes que se pensou naquelas enganadoras melhoras que muitas vezes aparecem no decurso da menin- 
gite tuberculosa, atribuídas à desidratação da substância cerebral e queda relativa da pressão intracraniana, mas que não dưram sinão 24 a 48 horas.

Como as injeçōes intra-raqueanas iniciais, muito frequïentes, não fôssem bem toleradas e despertassem forte reação, passou-se a fazê-las mais espaçadas, isto é, cada 24 horas, na dosagem de $100.000 \mathrm{U}$. por vez. Ao mesmo tempo passamos a. usar a via intramuscular com espaços de 4 horas, na dose de $200.000 \mathrm{U}$. por vez. Três dias depois, as melhoras já eram bem evidentes: lucidez perfeita, desaparecimento dos vómitos, normalização do pulso, alimentação mais fácil. e, até, uma evacuação espontânea. Persistiam, entretanto, a ptose da pálpebra direita, o dermografismo e a hipertermia. As melhoras clínicas não foram acompanhadas por uma queda paraleia da temperatura. Sabíamos que a estreptomicina. entre outras manifestações tóxicas, pode provocar hipertermia, o que tornava difícil a interpretação do comportamento da curva térmica. Por essa época, animados con a melhora dos sintomas clínicos e havendo dúvidas quanto à existência de intoxicação medicamentosa, resolvemos diminuir as injeções intramusculares para $600.000 \mathrm{U}$. por dia e fazer as injeçōes intratecais em dias alternados, o que estava de acôrdo com instruções que haviam chegado da América do Norte com nova partida de medicamento.

Convém assinalar que, por essa altura, como a pesquisa sistemática do bacilo de Koch fôsse sempre negativa no líqüido e como a cohaia inoculada ainda rão. apresentasse reação ganglionar, em face das melhoras clínicas espectaculares e rápidas, chegamos a pôr em dúvida a exatidão do diagnóstico. Entretanto, a negatividade de novos exames otoscópicos, de novas radiografias de crânio e seios da face e da reaçăo de Widal, não autorizava qualquer outra suposição. Pelo contrário, nova reação positiva à tuberculina e nova radiografia dos pulmões mos. trando acentuação da sombra hilar direita vieram afirmar ainda mais as possibiliddes de certeza diagnóstica.

Depois de 10 dias de tratamento, quando o doente já havia recebido 9.000 .000 $\mathrm{U}$. por via intramuscular e $440.000 \mathrm{U}$. por via intratecal, a moléstia entrou em fase mais ou menos estacionária, tendo como sintoma dominante a hipertermia, oscilando entre $38^{\circ}$ e $39^{\circ} \mathrm{C}$. Não havia vómitos, a cefaléia cedera, a consciência era boa, a ptose palpebral havia regredido em grande parte, não hahvia rigidez pupilar e o doente alimentava-se bem. As modificações do líqüido cefalorraqueano processaram-se lentamente; a normalização da taxa do açúcar se deu após uma semana de tratamento e a de cloretos só atingiu a normalidade depois de 20 dias. Persistia sempre o quadro inflamatório com hipercitose, aumento das proteínas e formação do retículo fibrinoso, quadro êsse que, com oscilações para mais o:t menos, se manteve até o final do tratamento. Do ponto de vista do líquor, a tolerância para as primeiras doses de Estreptomicina foi boa, não havendo grande reação celular após as injeçôes intratecais. Sòmente quando as doses foram elevadas de 25.000 para 100.000 U. houve forte hipercitose (1785 células por mm. ${ }^{3}$ ) e aumento da permeabilidade da barreira hemoliquórica, traduzida pela elevação da taxa do açúcar e abaixamento da de cloretos. Nests condições, resolvemos suprimir temporàriamente as injeçöes intra-raqueanas, visando poupar o doente e observar se as modificaçōes do líqüido e a hipertermia eram conseqüentes à irritação medicamentosa.

Dois dias depois, a cobaia inoculada apresentava evidente enfartamento ganglionar e, três dias mais tarde, a confirmação do diagnóstico se fêz pelo achado do bacilo de Kock no líqüido cefalorraqueano. Diante dêsses fatos e como, depois de 9 dias de repouso da via intratecal, a temperatura não se modificasse, foi retomado o tratamento por via raqueana com $50.000 \mathrm{U}$. em dias alternados. ao mesmo passo que se elevou para 800.000 U. a dose diária por via intramuscular. Em uma das vezes foram aplicadas, em um dia, por engano, $1.800 .000 \mathrm{U}$. e como 
a temperatura caisse e o paciente passasse bem, resolvemos mantê-la mais tempo. A tarde, todavia, o paciente teve dôres articulares, dôres nos membros inferiores e mal-estar. Resolvemos, por êsse motivo, suspender o medicamento durante o dia seguinte e, em seguida, recomeçar com doses menores de $300.000 \mathrm{U}$. intramusculares e $25.000 \mathrm{U}$. intratecais, em dias alternados. Diante do exame hematológico então feito, resolvemos fazer nova transfusão de sangue.

A esta altura do tratamento a situação era boa, excetuadas as reações que se seguiam às injeções raqueanas. $O$ doente sentava-se espontâneamente $e$ uma vez quis até ficar de pé. Ao exame clínico nada mais se encontrava senão reflexos patelares exaltados e clono dos dois pés. A temperatura entrou em fase de oscilaçōes bruscas, com baixas matutinas. Depois de 28 dias de tratamento, quando já havia recebido $710.000 \mathrm{U}$. intra-raqueanas e $21.300 .000 \mathrm{U}$. por via intramuscular, o doente apresentou súbita e estranha reação: tendo passado um dia um pouco agitado, bruscamente, à noite, a temperatura subiu a $39,5^{\circ} \mathrm{C}$ e surgiu forte cefaléia com gritos lancinantes, palidez, pulso quase incontável e grave estado geral; o exame clínico não revelou, entretanto, nenhuma alteração séria para $u$ lado do sistema nervoso. Seguiu-se abundante sudorese, queda da temperatura a $35,4^{\circ} \mathrm{C}$, pulso a 120 p. m. e pressão arterial $96 / 60$; depois de sono reparador, o doente acordou disposto, como se nada houvesse acontecido. Pensou-se em surto hipertensivo intracraniano tardio ou em reação medicamentosa. Foi resolvido prudentemente manter a dose de $300.000 \mathrm{U}$. diárias por via intramuscular e para as injeções intra-raqueanas passou-se a usar, em lugar da Estreptomicina Lederle, a procedente da firma Lily, que nos pareceu mais pura, na dose de $25.000 \mathrm{U}$. Desde então não se produziu reação apreciável, havendo até tendência a decréscimo da curva térmica.

Pela primeira vez, depois de tanto tempo, o doente pasou todo um dia sem febre e nós, que já conjeturávamos auxiliar a ação da Estreptomicina com o emprêgo do Promin, resolvemos contemporizar. Aliás, a situação não era má e o estado geral era satisfatório e clinicamente nada restava senão o clono do pé e, ao sentar-se, certa rigidez da coluna, o que poderia ser levado a conta do traumatismo repetido das punções raqueanas. Já estávamos resolvidos a suprimir a via intra-raqueana e manter sòmente a intramuscular na dose de $600.000 \mathrm{U}$. diárias, quando nos chegou da América do Norte a resposta telegráfica do Prof. MacIntosh, a quem havíamos consultado e que aconselhava elevar a dosagem para 800.000 U. intramusculares e $50.000 \mathrm{U}$. por via intra-raqueana diàriamente pelo espaço de 2 semanas, no mínimo, a menos que surgissem sinais de lesão do oitavo nervo ou disfunção vestibular.

Seguimos à risca aquelas instruções mas, ao aproximarmo-nos do fim do esquema, a situação se agravou de tal modo que fomos tomados de desânimo. As injeções intratecais repetidas despertavam forte cefaléia e perturbações nervosas, que se traduziam, às vezes, por desvios oculares passageiros. Os vómitos conseqüentes às injeções dificultavam a alimentação já de si agravada pela inapetência. Ajunte-se a isso um estado de fobia, de temor às injeções que perturbava o repouso. Em um dos dias suprimimos a injeção raqueana. Foi então resolvido, por œrtas razões que serão expostas mais tarde, dançar mão do Promin como terapêutica coadjuvante, nas seguintes doses: uma injeção intravenosa de $1 \mathrm{cc}$. no primeiro, 2 injeções de $1 \mathrm{cc}$. no segundo e 2 de $1,5 \mathrm{cc}$. nos dias subseqüentes até completar 7 dias. Para usar êste novo medicamento nos cercamos de todos os cuidados, observando a tolerância com repetidos hemogramas e dosagens de hemoglobina. Logo ao primeiro dia surgiram certas manifestações caraterizadas por grande perda de apetite, vómitos, cefaléia e, em uma das vezes, forte reação com taquicardia, respiração irregular, pulso rápido e fácies de choque. Como, entretanto, o sangue não mostrasse alterações específicas, prosseguimos. Ao mesmo tempo 


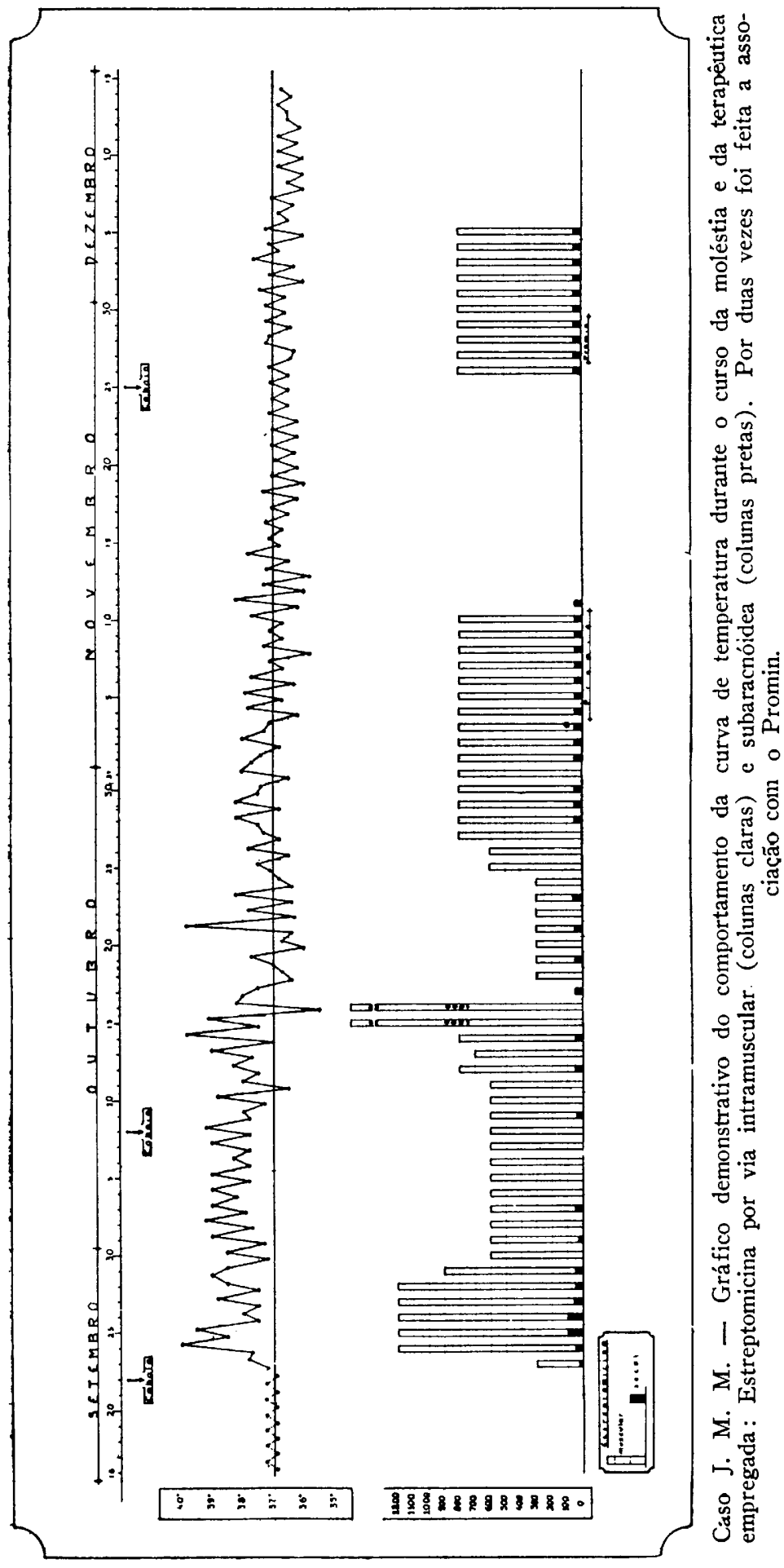




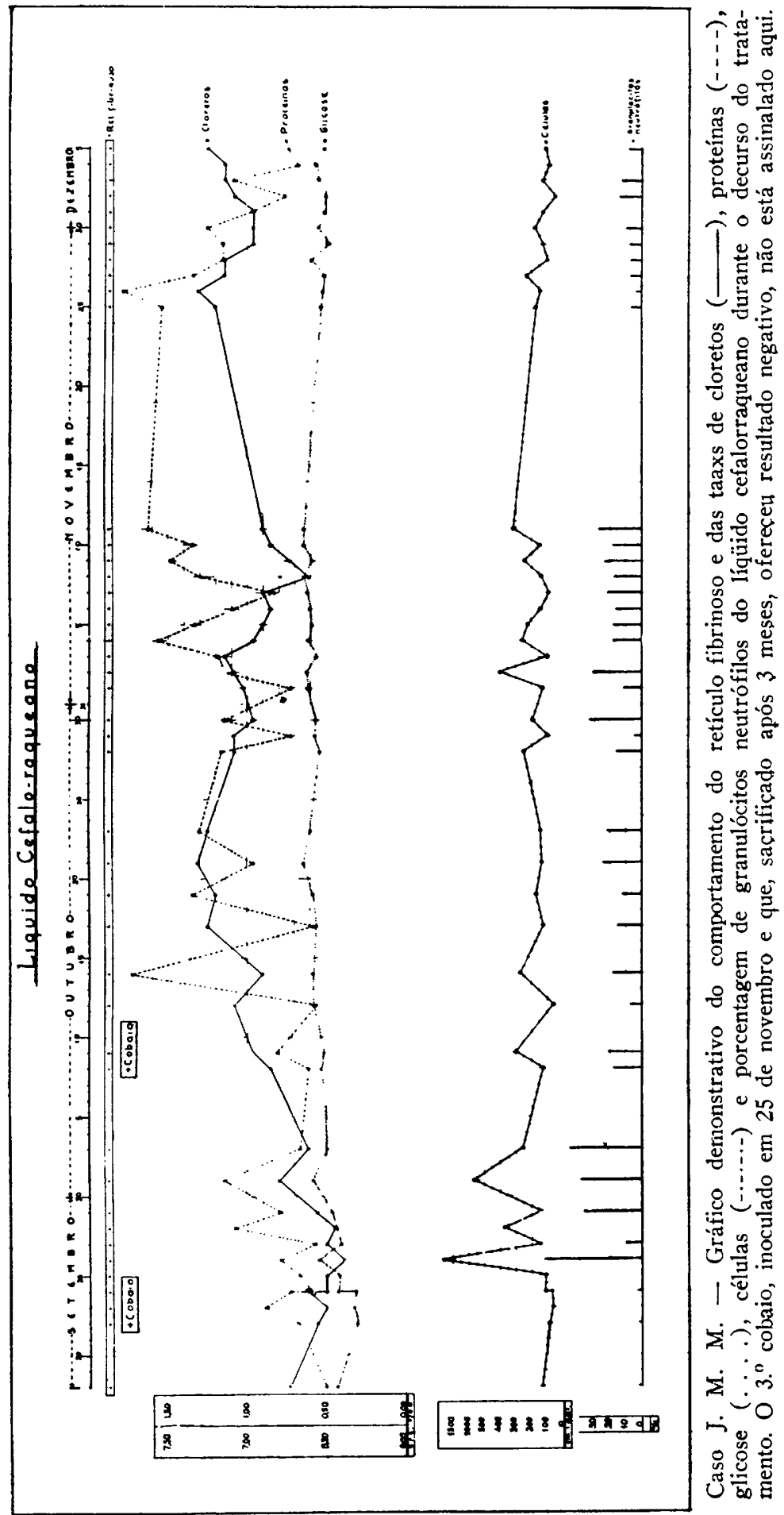


praticávamos sucessivos exames clínicos e especializados, hemogramas e provas de hemossedimentação. O exame otológico concluiu pela integridade dos labirintos e ausência de sintomas objetivos do aparêlho vestibular, bem como a prova audiométrica. O exame da vista revelou motricidade, reflexos e fundo de ôlho normais. O líquor, examinado diàriamente, acusava tendência à baixa na taxa dos cloretos, o que podia correr por conta dos vómitos persistentes e deficiente alimentação, fenômenos èsses ligados ao tratamento.

Terminada esta série de injeçōes, em cujo decurso o doente passou relativamente mal, foi suspensa tôda medicação e ficamos na espectativa. Dias depois, já com dois meses de tratamento, as melhoras eram bem evidentes: bom humor, bom apetite, aumento visível de pêso, noites repousadas e quase normalização da curva térmica, tudo fazendo supor a marcha vitoriosa para a cura. Não obstante, nova punção de prova, praticada depois de 14 dias de descanso, mostrou, apesar da normalidade da taxa de cloretos e de glicose, a persistência da elevada taxa de proteínas, da hipercitose e da formação do retículo. Diante dêstes resultados foi procedida a inoculação de terceiro cobaio.

Como o estado geral do paciente fôsse bom e favorável a um novo ataque terapêutico, digamos, a uma cura de consolidação, resolvemos fazer outra série de Estreptomicina, durante 10 dias, nas mesmas doses preconizadas por MacIntosh e também já associada ao Promin durante 5 dias $(1 \times 1$ cc., $2 \times 1$ cc.. $2 \times 1.5$ cc., $2 \times 1,5$ cc. e $1 \times 1,5 \mathrm{cc}$.), série que foi melhor suportada; as reaçōes foram mais brandas, não havendo necessidade de interrompê-la, como ocorrera nas vezes anteriores. Depois, demos por terminado o tratamento: o doente recebera, em 71 dias, o total de 44.600 .000 U. de Estreptomicina. sendo 42.650 .000 por via intramuscular e 1.950 .000 por via intra-raqueana, em 41 punções lombares e subocci pitais.

\section{COMENTÁRJOS}

Quando se relata um caso de meningite tuberculosa cuja evolução se processa no sentido da cura, surge desde logo a questão relativa à exatidão do diagnóstico. No caso presente, tendo a moléstia evoluído para a cura, faltou um dos caraterísticos da meningite tuberculosa: a evo1ıção inexorável para o êxito letal. O nosso diagnóstico não pode, entretanto, deixar dúvidas: o contágio, a prova da tuberculina, a evolução clínica inicial com seus sintomas caraterísticos, e o quadro liquórico constituem os sinais de presunção. O diagnóstico de certeza foi dado pela demonstração do bacilo no líquor e pela reprodução experimental da tuberculose após a sua inoculação em dois cobaios. $O$ primeiro cobaio, inoculado nos dias iniciais da moléstia, morreu 50 dias depois da inoculação e sua autópsia revelou: "gânglios ingüinais direitos numerosos, volumosos e contendo material caseoso, onde verificamos a presença de numerosos bacilos ácido-resistentes. Além dessas lesões, verificamos gânglios ilíacos caseificados. $O$ baço apresentava-se atrófico e com granulações" (Dr. J. B. Reis). O segundo cobaio, inoculado na terceira semana de moléstia, apresentou à autópsia quadro semelhante ao precedente. Insistimos nestes detalhes, pois parece não ser suficiente para o diagnóstico exato a simples demonstração do bacilo ácido-resistente no liquor: é necessária a inoculação para demonstrar a atividade do bacilo 
encontrado. E o que se conclui de um caso de Keith ${ }^{1}$ onde foi posta en dúvida a veracidade do diagnóstico desde que, não obstante o isolamenio do bacilo no líquor, o cobaio inoculado não demonstrou atividade do mesmo. Embora o diagnóstico clínico fôsse convincente, o caso foi catalogado como presuntivo.

A meningite tuberculosa, de prognóstico absolutamente fatal segundo a maioria dos estudiosos, é apresentada, entretanto, em algumas estatísticas. como passível de cura. A última estatística publicada por Krafchik ${ }^{2}$ refere que existem na literatura 60 casos que terminaram pela cura; no entanto, em grande numero dêles, a autenticidade do diagnóstico é posta em dúvida. Sem -querermos nos alongar muito sôbre a questão dos diferentes meios propostos para o tratamento da meningite tuberculosa no passado, todos êles sem fundamento, e também sôbre a :nedicação auxiliar de que lançamos mão, inclusive as sulfonas e a vitamina $\mathrm{D} 2$, julgamos de interêsse referir apenas o que tem sido obtido com a Estreptomicina.

Este poderoso antibiótico, produzido pelo Actinomyces griseus, foi obtido por Schatz, Bugie e Waksman em 1944. É preparado como sulfato ou cloridrato, solúvel na água, relativamente termostável e pode ser ministrado por via subcutânea, intramuscular, intratecal e nas cavidades pleural ou peritoneal. No nosso doente usamos Estreptomicina de duas procedências: a Lilly em pó, em frascos de um milhão de unidades, ou seja um grama, e que diluímos em sôro fisiológico, e a Lederle, que nos chegou às mãos já diluída, em frascos de $20 \mathrm{cc}$, com 2.000 .000 de U. ou 2 gramas por frasco.

Pondo de lado os seus efeitos sôbre outros germens, principalmente us Gram-negativos, interessa referir a atividade da Estreptomicina sôbre o bacilo da tuberculose, demonstrada por Feldman e Hinshaw ${ }^{3}$. Estes autores provaram a ação inibidora da droga na tuberculose experimental dos cobiaos, e depois, no homem. Após numerosas investigações no homem. Hinshaw ${ }^{4}$ expressa a opinião de que a Estreptomicina tem ação moderadora da infecção, exercendo atividade bacteriostática sôbre o agente da tuberculose. Em janeiro de 1946. Cook, Dunphy e Blacke ${ }^{5}$ publicaram o primeiro caso de cura clinica e bacteriológica da M. T. em crian-

1. Keith, M. K. - Use of chemotherapy in a case of tuberculous meningitis. Proceed. Staff Meetings Mayo Clinic, 19:36 (janeiro, 26) 1944.

2. Krafchik, L. - Tuberculous meningitis treated with streptomycin. J. A. M. A., 132:316-317 (outubro, 19) 1946.

3. Feldman, W. H. e Hinshaw - Effects of streptomycin on experimental tuberculosis in guinea pigs: a preliminary report. Proc. Staff Meet. Mayo Clinic, 19:593 (dezembro, 27) 1944.

4. Comissão de Agentes Quimioterápicos, do Conselho Nacional de Pesquisas dos Estados Unidos da América - Streptomycin in the treatment of infections. J. A. M. A., 132:70-77 (setembro, 14) 1946.

5. Dunphy, C. e Blake - Streptomycin in tuberculous meningitis. A report of its use in 1 year old infant. Yale J, Biol, a. Med., 18:221 (janeirn) 1946. 
ça de um ano de idade. Esses êxitos experimentais e clinicos encontraram apôio, talvez, $\mathrm{n}_{0}$ moderno conceito anátomo-patológico da M. T., introduzidos por Rich e Mc Cordock ${ }^{6}$. Até ha pouco tempo a idéia dominante era de que a M. T. seria a manifestação meningea da tuberculose miliar generalizada. Hoje pensa-se que, na grande maioria, há um foco cerebral, cortical ou juxtameningeo pré-existente, donde irrompe a contaminação meningea e que $o$ aparecimento da meningite na tuberculose miliar é consequência da reativação do foco acima referido.

A toxidez da Estreptomicina é mínima, mas ela tem, por vezes, o inconveniente de apresentar reações semelhantes às da histamina, principalmente nos produtos pouco purificados. Estas reações se caraterizam por cefaléia, artralgias, náuseas, hipertermia e, também, manifestações cutâneas tais como "rash" eritematoso e urticarial. Em nosso caso, como muitos dêstes fenômenos se confundiam com os sintomas da moléstia, não havia elementos seguros para avaliar até que ponto êles seriam atribuíveis à ação tóxica do medicamento. Outras manifestações tóxicas de maior relevo, particularmente nos doentes submetidos a doses altas e prolongadas, são as vertigens, os zumbidos e a surdez, por vezes irreversiveis. As Estreptomicinas empregadas em nosso doente foram prudentemente examinadas na sua atividade antibiótica pelo Prof. Ettore Biocca em provas de laboratório, usando amostras de Staphylococus aureus. O nosso estoque sempre mostrou boa atividade.

Vejamos agora quais os resultados obtidos sôbre a meningite tuberculosa com êste antibiótico. A literatuna inglêsa é pessimista. As tentativas feit.as por Cairns e col. ${ }^{7}$ em 2 casos de M. T. deram o seguinte resultado: o primeiro veio a falecer 8 horas depois do início do tratamento e o outro apresentou reações tão alarmantes após a primeira injeção intratecal rute o tralamento foi suspenso. Quinto aos trabalhos anericanos aue conhecemos através das revistas médicas e da troca de correspondência $\mathrm{c} c \mathrm{~m}$ a Dra. Hattie Alexander, assistente do Prof. Mc Intosh e encarregada do tratamento pela Estreptomicina em várias infecções podemos, em resumo, relatar os seguintes resultados: Em relatório feito ao Comité encarregado de pesquisas sôbre agentes quimioterápicos, o Dr. Hinshaw, discutindo os resultados de seus estudos sôbre a Estreptomicina nas várias formas de tuberculose. apresentou, em junho de 1946, sete casos de meningite: dêstes pacientes, um apresentando M. T. associada a tuberculose miliar, morreu no $5^{\circ}$ dia de tratamento; os outros 6 apresentaram sinais de melhoras clínicas. Dêstes seis, quatro ainda estão vivos, sendo êstes os únicos que rece-

6. Rich, A. R. - The pathogenesis of tuberculosis. Ch. C. Thomas, 1944.

7. Cairns, H., Duthle, E. S., e Smith, H. V. - Intrathecal streptomycin in meningitis. Clinical trial in tuberculous coliform and others infections. Irancet, 251:153, 1946. 
beram Estreptomicina por via intramuscular e intra-raqueana. Mas o prognóstico dêstes 4 casos "é extremamente duvidoso", diz êle; um está cego, um está surdo, outro tem sintomas bulbares pronunciados com disartria e talvez, atraso mental. Sòmente um dêles näo apresenta seqüela neurológica, exceto a paralisia de um músculo ocular. Quanto ao líqüido cefalorraqueano, sòmente em um dêles ficou normal; em todos os outros, embora se normalizasse a taxa de glicose, permaneceram, como resíduo, hipercitose e hiperproteinorraquia. Infelizmente não conseguimos ainda obter as observações detalhadas dêsses casos. Seria dc interêsse saber se as lesões nervosas apresentadas já existiam antes do tratamento e não puderan ser removidas. Em outubro de 1946, Krafchik $^{2}$ relatou um caso de $M$. T. em criança de 15 meses tratada com Estreptomicina, quasi consecutivamente, durante dois meses, sendo aplicadas 24.000.000 U. intramusculares e 2.800.000 U. intratecais. A criança foi dada como curada sem nenhuma seqüela neurológica. Um mês depois o liquiido cefalorraqueano ainda mostrava pleocitose e o exame radioscópico, aumento da sombra hilar. Mais recentemente, em cartarelatório que nos foi enviada em 7 de novembro de 1946, a Dra. Hattie Alexander é mais pessimista. Ela nos informou que, nos casos em que foi possivel prolongar a observação até 6 meses após a cura clínica, vários doentes têm apresentado recidivas. Não nos informou, porem, se essas recidivas foram fatais ou se cederam a novo tratamento.

No decurso do tratamento. por duas vezes. fizemos uso do Promin, pelos seguintes motivos: é do conhecimento geral que certas sulfonas têm aprsentado resultados encorajadores quando empregadas em animais de laboratório infectados com bacilos tuberculosos. Entre nós, o Prof. Quintino Mingoja tem estudado êsse assunto e muito nos encorajou. $\mathrm{Na}$ América do Norte, na Clinica Mavo, há um caso de cura em criança de 2 anos, relatado por Keith ${ }^{1}$. Este autor empregou o Promizole, mas o diagnóstico foi posto em dúvida por falta da prova de cobaio. Entre nós, tentativas feitas, mas não publicadas, não têm dado resultado. Em 1945, entretanto, Smith e Mc Closky ${ }^{8}$ demonstraram que a Estreptomicina e Promin, quando administrados juntos em cobaios infectados com bacilos tuberculosos humanos, exercem ação quimioterápica maior do que aquela que se poderia esperar de uma simples soma de efeitos; a ação sinérgica é mais que duplicada. A Dra. Hattie Alexander nos escreveu: "não temos experiência com o Promin, mas trabalhos experimentais em animais (e cita os autores acima) mostram que a ação combinada do Promin e Estreptomicina é superior à da Estreptomicina só". É bem de ver que esta nossa tentativa, por ser a primeira ao que saibamos feita no homem, realizou-se com muitas cautelas

8. Editorial - Streptomycin-promin therapy. J. A. M. A., 132:516-517 (novembro, 2) 1946. 
e talvez com doses insuficientes. Dessa ação sinérgica não pretendemos tirar conclusões e preferimos sòmente relatar as reações observadas e assinaladas em nosso relato. Qualquer que seja, entretanto, o resultado obtido, temos sempre que dar maior valor ao antibiótico, e qual desde o início cio tratamento apresentou um resultado brilhante, mudando inteiramente e de modo convincente a marcha fatal da moléstia.

Do que acabamos de expor podemos concluir o seguinte: nesta data, decorridos já 4 meses do início da moléstia e 40 dias depois de suspensa tôda a medicação, J. M. apresenta-se com todos os caraterísticos de uma criança normal, bom estado geral e excelente pêso. $\mathrm{O}$ exame neurológico, praticado há três dias, revelou, excetuando ligeira incoordenação dos movimentos, que vem regredindo, normalidade do sistem $a$ nervoso. Não temos, todavia, a intenção de afirmar que não surjam recidivas; o período de observação é ainda curto para tal afirmação. Mas a cura clínica, a normalização das taxas de glicose e de cloretos e o desaparecimento do bacilo no líqüido cefalorraqueano são elementos ponderáveis que justificam o êxito terapêutico. Resta, ainda, no líquor, uma hipercitose linfocitária de 72 células por $\mathrm{mm} 3$, um aumento de proteínas de 1,10 gr. \% e a presença do retículo fbrinoso, dados êsses residuais e que têm sido até agora observados nos casos dados como curados na literatura conhecida.

\section{RESUMO}

Trata-se do primeiro caso publicado no Brasil de meningite tuberculosa, em menino de 5 anos de idade, tratado com sucesso pela Estreptomicina. O diagnóstico foi firmado pelo achado do bacilo de Koch no líquiido cefalorraqueano e pela inoculação em cobaio. $O$ tratamento foi iniciado no $8 .^{\circ}$ dia depois de se declararem os sinais da meningite $e$ durou 71 dias, tendo o pacente recebido um total de $44.600 .000 \mathrm{U}$. de Estreptomicina, sendo $42.650 .000 \mathrm{U}$. por via intramuscular e $1.950 .000 \mathrm{U}$. por via intratecal, em 41 punções lombares e suboccipitais. Durante o tratamento, em sua fase final. foi associado o Promin. Os autores acreditam que os resultados obtidos se devem, entretanto, à Estreptomicina, com a qual, desde o início do tratamento, se modificou de maneira nítida a marcha da moléstia. Apó 40 dias de terminado o tratamento, o paciente se apresentava como uma criança normal, sem apresentar seqüela neurológica alguma. Repetidos exames do líqüido cefalorraqueano mostraram progressiva diminuição das alterações, restando, no final, apenas hipercitose linfocitária de 72 células por $\mathrm{mm} 3$, aumento da taxa de proteínas e fino retículo fibrinoso. Os autores, apesar dos brilhantes resultados obtidos, não afirmam a cura completa, dado que o período de observação ainda é julgado insuficiente para uma apreciação definitiva. 


\section{SUMMARY}

This is the first report, in Brasilian medical literature, of a case of tuberculous meningitis in a child 5 years old, successfully treated with Streptomycin. Koch bacillus was evidenced in the cerebrospinal fluid and the innoculation in guinea pig was positive. Treatment started 8 days after onset of the meningeal signs; it lasted 71 days, being the total dose of Streptomycin 44,600,000 units $(42,650,000$ intramuscularly and 1,950,000 intrathecally, by means of lumbar and cisternal punctures). Promin was associated to Streptomycin in the last days of treatment. The authors believe, however, that the results were due to Streptomycin alone, which, since therapy was started, definitely improved the course of the disease. After 40 days that the treatment was discontinued the patient showed normal behavior, with no neurological sequelae. Repeated tests of cerebrospinal fluid denoted progressive improvement, and, at the end, there was only lymphocytic pleocytosis ( 71 cells by $\mathrm{mm} 3$ ), increase of the protein content and a thin fibrinous reticulum. In spite of these good results, the authors cannot affirm a complete recovery, because the time of observation is still too short to allow a definite estimation.

R. Sete de Abril, $397-8 .^{\circ}$ a. - São Paulo

Nota - Esta comunicação foi impressa depois de decorridos 5 meses após o término do tratamento. Os autores desejam declarar que o doente e o liquor se apresentam normais, permitindo admitir ter sido obtida a cura completa.

Note - This paper has been printed after a period of 5 months has elapsed since the treatment was completed. The Authors would like to acertain that the patient and the liquor are perfectly normal and therefore it may be concluded that a complete recovery was attained. 